\title{
Towards a theory of small-firm low-tech food innovation
}

\author{
Vijay Vyas ${ }^{1}$ and Renuka Vyas ${ }^{2}$
}

\begin{abstract}
Innovation in low-tech sectors such as food \& drinks continues to be under-researched and undertheorised despite growing evidence on low and medium technology sectors' substantial contribution to economic growth in the developed countries. This attempt to build theory from case study research, contributes to an embryonic literature in this area through a set of propositions grounded in process theory and organisational innovativeness literature. We postulate that small firm food innovation is shaped exogenously by the cultural context of food consumption and internally by highvariety-low-volume manufacturing environment of the innovative firm. The ensuing incremental innovation is underpinned by a counterintuitive avoidance of development of health foods. These innovative efforts are abetted by the large retailers who, in turn, use these agile enterprises' creativity and plasticity to achieve their own competitive goals. The propositions outlined here complement the extant theory through a sharper contextual focus in contrast to the previous research.
\end{abstract}

Key words: SMEs; low-tech; innovation; food \& drinks; Scotland

\section{Introduction}

Strong links between innovation and business performance has been consistently reported in the research over the last 5 decades (Mansfield, 1968, 1971; Freeman, 1974; Grabowski \& Mueller, 1978; Cavanagh \& Clifford, 1983; Dosi, 1988; Pavitt, 1991; Nonaka \& Takeuchi, 1995; O’Gorman, 1997; Frenz, Michie \& Oughton, 2003). A significant part of this research, however relates to the large business and often looks at innovation from a high-technology outlook. Innovative accomplishments of SMEs in traditional and low technology sectors have not been analysed with equal rigor or persistence (Menrad, 2004; Sankaran \& Mouly, 2007). Some exploratory work has recently emerged that reports the significance of low-tech small firm innovation. Petrou \& Daskalopoulou (2009) for instance show that innovation activities influence growth in low-tech

\footnotetext{
${ }^{1}$ Portsmouth Business School, University of Portsmouth, UK

${ }^{2}$ Independent researcher, Portsmouth, UK
} 
small firms as well. It has been also highlighted that firms in low and medium technology sectors, pursue innovation with significant commitment and their contribution to economic growth is much greater than those of firms in high-technology industries even in the developed countries (HirschKreinsen, 2008; von Tunzelmann \& Acha, 2005). The empirical evidence too is stacked against the contention that high-technology firms are the sources of production, productivity or jobs growth in advanced economies (Sandven, Smith and Kaloudis, 2005). Despite this, there have not been many studies of small-firm innovation in industries such as food and drinks. Robertson, Smith \& von Tunzelmann (2009) highlighting the 'large-scale cross-sectional' nature of current research on innovation in low-and medium-technology industries conclude that this unilateral research focus has led to significant 'gaps in our understanding of innovation' in these sectors. They advise 'detailed studies of individual sectors' to fill this 'missing link'. Through the case studies of seven innovative Scottish food companies, this study attempts to contribute towards this task. Broadly following the approach proposed by Eisenhardt (1989) on building theories from case study research, it generates a set of propositions and discusses the congruence as well as the conflict between these propositions and the extant literature.

\section{The research context: Scottish food and drinks industry}

Food and drinks is an important industry in Scotland. It is one of its biggest employers and its top exporter (Leatherhead Food International, 2005). This sector, dominated by Small firms In Scotland, has undergone a continued reorganisation. In the last decade and half, the number of businesses and employment has steadily declined whereas business turnover, turnover per unit and gross value added per employee has gone up (Scottish Business Statistics, 2010). This is a classic industry shake-up scenario where weaker companies have exited, stronger companies have survived and 
have gained further strength. As competitiveness is closely linked with, the ability to innovate (Dosi, 1988; Rama, 2008) there is a-priory expectation of innovation in the surviving successful companies. The Scottish food and drinks sector, thus, provides an ideal setting to investigate small firm innovation in this industry.

\section{Conceptual framework}

Wolfe (1994) recognises Organisational Innovativeness as one of three main innovation research streams. It deals with identifying explicitly or otherwise, the determinants, drivers or antecedents of innovation. Process Theory Research, the other research stream, visualises innovation as a cluster of events, not necessarily chronological or linear (Krishnan, Eppinger \& Whitney, 1997) that culminates in new product or process development. These two themes (for which we have used here the terms the determinant perspective and the process perspective) capture a very substantial part of empirical and theoretical microanalysis of firm level innovation.

The origins of the determinant perspective to the study of innovation and other phenomena within the social sciences could be traced to Francis Bacon's pioneering work on the scientific method (Bacon, 1902). At the core of the scientific method is formulation of a hypothesis and its subsequent verification by the examination of empirical data. Though, this approach has been successful in the study and advancement of knowledge within natural sciences, its epistemological legitimacy and appropriateness in the study of social phenomena have been often questioned (Morgan \& Smircich, 1980). It is argued that due to a stochastic, evolving and fluid nature of social phenomena and intrinsically subjective nature of our knowledge about them, deterministic methods are not suitable for their exploration. Despite this, extensive use of these methods in social science research has 
continued and a voluminous literature on the determinants of innovation, some of which is listed below, is a testimony to it.

In contrast to a sizable deterministic research on innovation, some influential and equally prolific, scholarly work on innovation from a process perspective has also emerged. It is argued that the process perspective to the phenomenon of innovation, particularly amongst SMEs, is more meaningful and relevant than its determinant based view because of its sensitivity to the 'microprocesses of innovation' and its ability to explain 'the embededness of innovation in SMEs' (Edwards, Delbridge \& Munday, 2005). Many scholars such as Hoholm \& Araujo (2011) have, thus responded to a 'call' for more prescriptive, process studies of innovation.

Process perspective, despite its above-mentioned qualities and its ability to answer the question

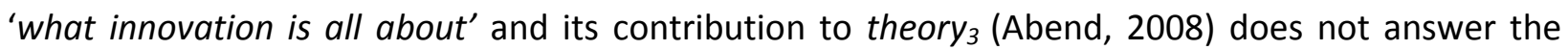
question 'what causes innovation' as precisely as the deterministic approach purportedly does and thus fails to contribute to theory ${ }_{1}$ (Abend, 2008). Without getting into an avoidable debate on the relative merits of theory $y_{1}$ and theory $y_{3}$, we take a constructive way forward and combine these two perspectives, explore both the questions simultaneously and build theory ${ }_{1}$ and theory ${ }_{3}$ concurrently on the premise that the questions 'what causes innovation' and 'what innovation is all about' are both substantive and complementary and are not competitive. Moreover, as a rich description is a prerequisite to building a theory (Mintzberg, 1979; Weick, 2007) we deduce that exploring a phenomenon from a single perspective entails an unnecessary loss of detail and of consequent richness of description, compromising the quality of emergent theory. It is suggested that the process to build theory from case study research should culminate in well-defined concepts or 
testable propositions (Eisenhardt, 1989; Eisenhardt \& Graebner, 2007). We argue that the probability of achieving this goal is enhanced if the phenomenon is explored and evidence is scrutinised from multiple perspectives. This is consistent with a post-positivist approach to theory development which 'relies on multiple methods as a way of capturing as much of realty as possible' (Denzin \& Lincoln 1994; Wilson \& Vlosky, 1997). One downside of incorporating multiple perspectives may be possible generation of far too many propositions, some of them at odds with others. As one of the desirable qualities of a good theory is parsimony (Eisenhardt, 1989), a research approach engendering too many propositions, it could be argued, represents a methodological profligacy compromising the value of the evolving theory on the parsimony scale. However, it could be counter-argued and perhaps more plausibly that parsimony is not warranted at the stage of generation of propositions, as propositions not yet tested and confirmed are not a theory. Further, in our opinion, profligacy in generating propositions and parsimony in shaping the final theory is a better strategy because completeness too is an equally vital attribute of a good theory (Whetten, 1989) and a research process generating a relative abundance of testable propositions has a better promise of producing a more complete theory. We also argue that, that multiple perspectives may sometimes lead to conflicting interpretation of evidence should not be a dissuasion as 'creative insights' often emerge from seemingly conflicting evidence (Cameron \& Quinn, 1988) a welcome step in the process of building theory from case study research (Eisenhardt, 1989).

Apart from the two above-discussed dominant perspectives to the study of innovation, our analysis incorporates two further related theoretical constructs. The first among these, arising from an environmentally contingent, policy theory of innovation and based on the premise 'context-causes- 
policy-causes-innovation' (Ettlie, 1983) represents, in our opinion, a fusion of the above two perspectives as it analyses the process of innovation from a causality stance. This therefore does not constitute a conceptual departure or dilution of our theoretical focus but a conceptual enrichment. Another theoretical perspective that we have used in this paper relates to the typology of innovation. Typology facilitates the classification of a phenomenon into judiciously standardised distinct categories and helps in its rich and still parsimonious interpretation (Slater \& Olson, 2001). Within the innovation typology, the one that differentiates radical innovation from incremental innovation (Garcia \& Calantone 2002; Greenwood \& Hinings 1993) is relevant to the present analysis.

\section{The state of general theory of business innovation ${ }^{3}$}

\subsection{Determinant-research outcomes}

The conclusions of capacious investigation of innovation from a determinants perspective can be better appreciated by dividing them in two parts, endogenous and exogenous determinants, which can be then divided in two further sub-parts strategic and non-strategic determinants. Endogenous strategic determinants crystallised by previous research include market-orientation (Kohli \& Jaworski, 1990), learning process quality (Cohen \& Levinthal, 1990), technology policy (Ettlie \& Bridges, 1982); use of cooperative networks (Beaver \& Prince, 2002) and managerial efficiency (Moore, 1995) whereas endogenous non-strategic determinants include characteristics of entrepreneur (Casson, 2003), innovativeness of people (Patterson, 2001), existence of innovative teams (Anderson \& West, 1998), financial adequacy (Beaver \& Prince, 2002) and age and size of enterprise (Acs \& Audretsch, 1990; Schumpeter, 1934; 1942). Degree of industry concentration,

\footnotetext{
${ }^{3}$ This is not purported to be a review of literature on business innovation. It lists only some of its main conclusions. A review of literature on food sector innovation follows in section 5 .
} 
barriers to entry, and intensity of competition are industry specific exogenous determinants (Acs \& Audretsch, 1990) whereas, regional economic performance (Roper, 2000); industrial policy and legislation (Antonelli \& Calderini, 1999); networks (Breschi, 1999); level of entrepreneurship (Acs \& Audretsch, 1990), potential for spin-off (Oakey, Rothwell \& Cooper, 1988), society's attitude towards innovation (Rothwell \& Zegveld, 1982) and headquarter branch ratio (Oakey, Rothwell \& Cooper, 1988) are region specific exogenous determinants.

\subsection{Process-research outcomes}

The process inquiry of innovation examines the constituent phases of the innovation process and explains the causal configuration of relationships of activities that lead to a new product or a new process. Within this literature, analysis of innovation within a stage-gate context has been the most noteworthy (Cooper, 1990; Cooper \& Kleinschmidt, 1994). Though the process theory literature is not exclusively stage-based analysis of innovation, stage thinking has dominated this perspective. A typical process stage model identifies various stages of development process, their order and linkages between the stages (Conway \& Steward, 2009). Cooper's stage-gate model improves the utility of stage models significantly by inserting an evaluation phase between each two successive stages. As impact on practice is an important virtue of a good theory (Whetten, 1989) and the impact of stage-gate models is undeniable, both in terms of the extent of their widespread use as well as the reported gains from their use Barczak, Griffin \& Kahn, 2009; (Ettlie \& Elsenbach, 2007), their pivotal place within the process theory literature is irrefutable. Among their weaknesses, however, are oversimplification of reality through a linear visualisation of innovation process and their inability to capture the overlapping and concurrent nature of innovation events (Brockhoff, 1999). 
Recently Cooper (2008) has tried to address these critiques and proposed more flexible 'xpress', 'lite' and 'spiral' variations. Despite this, in our opinion, due to its inexorable need to search for and explain the interconnectivity of process events that populate an innovation process, linearly or otherwise, the stage approach imposes an impoverishing restriction on scholars trying to build theory using it, as it forces them to omit events that do not fit a disciplined process description such as a stage-gate model. As a result, it could be argued that events 'at odds' with the rest of the process description might have been overlooked by the stage-gate researchers. However, as Eisenhardt (1989) suggests the observations, at odds with an anticipated pattern, are sometimes the sources of discoveries of significant value, we argue that regimented process descriptions such as stage-gate models, though are of value in planned NPD in well-ordered large corporations, in small entrepreneurial organisations, a loose process description without a deliberate attempt to fit it in a pattern is both more appropriate and more illuminating, at least at the pre-theory exploration phase of study.

\section{The state of theory on food sector innovation}

Research on innovation in the food and drinks sector continues to be exploratory and underscores a noticeable lack of novelty in its findings. It highlights a static approach to new product development in this sector, for the last many decades, both in process depiction as well as in antecedent identification. It seems that food and drinks companies continue to develop new products almost in the same way narrated by Nystrom \& Edvardsson in his 1982 article reporting on NPD by Swedish food companies. Though there are signs that some of the enterprises are bucking the trend and breaking new grounds (Mark-Herbert, 2004), not too many of them have taken uncharted routes 
and more importantly, those that have done so have not achieved any noticeable success to tempt others to follow suit.

Previous research consistently shows low R\&D to sales ratios in this sector in relation to other sectors (Galizzi \& Venturini, 1996; Sandven \& Smith, 1993). Jones (1995) from his global survey, Ilori, Oke \& Sanni (2000) in Nigeria and Capitanio, Coppola \& Pascucci (2010) in Italy confirm this. It seems that R\&D investments are not considered particularly rewarding by firms in this industry. The literature also shows that the incremental innovation is the mainstay of NPD in food and drinks industry. Koku (1998) for USA, Ernst \& Young (1999) and Martinez \& Briz's (2000) for Spain, Bogue \& Ritson (2006) for Ireland and Bhaskaran (2006) for Australia all report that food and drinks innovation is conspicuously incremental. However, no extant study specifies the precise nature of incremental innovation in this industry.

The evidence on development of health foods as the major thrust of NPD in food industry too is inconclusive. Though low-fat foods have been touted as most promising avenue of NPD in this sector (Longman, 2001), the reported failure of low-fat variants to deliver the expected premiums to their creators (Bogue \& Ritson, 2006) has raised a question mark on the commercial sense of an NPD strategy based on development of health foods. This theme though has remained largely unexplored in research on food industry innovation.

The literature also shows that the largest of food and drinks MNCs conduct innovation distinctly differently in comparison to smaller enterprises. Incurring substantial R\&D investments, they aspire for radical -and not incremental- innovation. Significantly, though, in these efforts, they do not 
succeed frequently and few Food and Drinks MNCs achieve noticeable success in this pursuit. Analysis of patent record of over 100 largest food and drinks MNCs in the world shows that it is rare for a food and drinks MNC to demonstrates an innovative spell exceeding 4 years and a minuscule minority of them obtain nearly $80 \%$ of the all patents due to all food and drinks MNCs (Alfranca, Rama \& von Tunzelmann, 2004). Given such none-so-glorious R\&D success of the largest of enterprises in this industry, it is understandable why small food companies do not want to emulate their larger cousins.

The literature on the subject attributes low research intensity, a focus on incremental innovation and lack of investment in R\&D in this industry to food consumers' significant conservatism, i.e. their reluctance to eat products, on a regular basis, that are very different from what they are used to eating. Innovators in this industry, thus face a stiff challenge in their attempts to make money by developing radically new food product (Nystrom \& Edvardsson 1982). Another relevant issue reported in the literature is a weak relationship between R\&D intensity and innovation success in the food and drinks industry (Galizzi \& Venturini 1996) confirming that the R\&D-averse conventional wisdom of small food companies is consistent by scholarly conclusions.

Substantial and increasingly intensifying large-retailer engagement with new product development in this industry is also noted in previous research. Hughes (1997) reports this for both UK and USA so does Stewart-Knox \& Mitchell (2003) for UK, USA and Denmark, Fortuin \& Omta (2009) for the Netherlands and Colurcio et al. (2012) for Italy and Switzerland. In this context, it is also noted that the large retailers specifically encourage small food SMEs to develop new products, which could be targeted at the high end of the value chain. They do this is to enhance their ability to compete with major food brands. However, Hingley \& Hollingsworth, 2003 note that this cooperation is not a 
partnership between the equals. The large retailers, due to their massive purchasing power enjoy a notable negotiating advantage vis-à-vis small food companies. van der Valk \& Wynstra (2005) report, perhaps as a manifestation of this equation, a coercive nature of relationship between the two, as large retailers often threaten small food companies with a loss of shelf space to competitors if they fail to innovate. The literature however does not explain the small food companies' motives in entering this unequal and coercive relationship.

Within-firm cross-functional cooperation is reported by Suwannaporn \& Speece $(2000 ; 2003)$ in 17 large as well as in 114 medium to large companies and by Dhamvithee et al. (2005) in 93 companies, nearly half of which are SMEs. This indicates the size neutrality of within-firm crossfunctional cooperation in innovation process in the food and drinks industry. Firm size, in itself, is a well-reported determinant of innovation in this industry. Avermaete et al. (2003), for instance, report it for Belgium and Dhamvithee et al. (2005) and Huq \& Toyama (2006) for Thailand.

To sum up, incremental innovation, low research intensity, cross-functional cooperation, influence of firm size and large-retailer involvement are the most widely reported features of innovation in food industry. The focus on incremental innovation, avoidance of 'unnecessary' high R\&D budgets and low research intensity are attributed to a distinct conservatism in consumption of food products in comparison to that of other products.

From the above analysis, the following 'research gaps' are identified.

\section{The knowledge gaps}

a. When a food company attempts to create a variation of its existing products, is this effort directed towards a specific route and if yes, why? 
b. Is the development of health foods, the major thrust of NPD in food sector?

c. Why do food companies willingly enter in a potentially disadvantageous and reportedly coercive relationship with large retailers for new product development?

\section{The methods gap}

Though most previous research investigates samples involving mixed firm sizes, it also shows that firm size is a significant determinant of innovation in this sector. Given this, it is imperative that a methodologically correct investigation of innovation in this industry should control for size.

3. The theory gap

Research on food sector innovation encompasses varied and disparate aspects of innovation. However, no attempt yet has been made to link these parts and present a comprehensive statement of a theory of small firm food innovation.

\section{Research objectives}

From the case studies of innovative small food companies, generate a set of propositions that reexamine the received theory, fill the existing research gaps and collectively constitute a comprehensive statement of theory of small firm food innovation.

\section{The research approach and methods}

This work utilises qualitative case study research and examines the evidence thus generated from a combined determinant-cum-process perspective using an interpretative lens. Case study research, despite its inherent formidable challenges, offers a unique opportunity to build a theory (Eisenhardt \& Graebner, 2007) and is considered amongst 'the most interesting' business research streams (Bartunek, Rynes \& Ireland, 2006). This work, heeding Easterby-Smith, Lyles \& Peteraf (2009) 
extends qualitative research to a traditional industry. Amongst the tools of qualitative research, personal interview, an efficient way to collect rich empirical data to investigate an 'episodic' and 'infrequent' phenomenon (Eisenhardt \& Graebner, 2007) is chosen here as the principal mode of inquiry. During interviews, following Johannessen, Olsen \& Lumpkin (2001) self-reports by 'key informants' are used as a basis to grasp the intricacies of product innovation in the case study companies. The semi-structured interviews are based on a set of themes emerging from business innovation literature encompassing organisational innovativeness and process theory strands discussed above.

From a list of Scottish food companies known for innovation obtained through consultation within the Food \& Drinks Cluster in the Scottish Enterprise, the business support agency of the Government of Scotland, a sample of twelve companies was chosen and each was approached with a request to participate in the research. This was a theoretical -and not a random-sample, most likely to reveal the phenomenon under scrutiny (Eisenhardt, 1989). People responsible for new product development in seven of the targeted twelve companies that agreed to participate in this research were subsequently interviewed. This group included the owners / entrepreneurs and senior executives. Notes were taken during the first two interviews and the remaining five interviews were digitally recorded. Noted interviews were written down immediately after and recorded interviews were later transcribed. Two teams of interviewers conducted three and four interviews respectively and on each team, there were at least two interviewers. This followed Eisenhardt (1989) advice on the use of multiple data collection teams, a la Pettigrew (1990), allowing a more objective perspective to the evidence when the data was cross-shared within the team. All respondents were contacted on many subsequent occasions to fill information gaps or seek further information. These interviews lasted up to two hours and provided a unique insight not 
merely into the process, determinants and typology of innovation in these companies but also a glance into the world of some exceptionally creative individuals, their motivations as well as the functioning of their organisations.

The data generated by the case studies was analysed using both within-case and cross-caseanalyses as advised by Eisenhardt (1989). To do this we first read and reread the interview summaries and transcriptions several times in a systematic search for dominant behaviours, actions and conducts reported by the majority of case study companies. Each one of these behaviours was then verbalised as an emergent proposition. In the next stage, we identified a set of theoretical constructs as well as sub-constructs, corresponding to these emergent propositions, from the previous research listed above. We then matched the propositions, each at a time, with these constructs in a systematic search to conclude if the evidence articulated in the emergent proposition was consistent with or at odds with an identified theoretical construct. This was an iterative process, meaning that often when we found an inadequate fit between a proposition and the corresponding theoretical construct that we had identified, we went back to the literature in search for alternative appropriate constructs to contrast them with it. We found that in many cases, it was difficult to conclude if there was evidence on a particular theoretical construct or not, however, in most cases it was relatively easier to find support -or lack of it- for the relevant subconstructs. For instance, it was difficult to draw a firm conclusion if a sample company's behaviour confirmed high market-orientation or not. However, it was not difficult to conclude if the sample company exhibited an ability to explore and reach potential markets. 
Early in the interview process, it became obvious that respondents were unusually creative. To confirm this formally, a questionnaire used to test the innovation proclivity of respondents was adapted from the one used and extensively validated by Patterson (2001) and administered on people responsible for new product development in the case study companies. This followed Eisenhardt's (1989) advice on adjustment in data collection instruments to 'probe an emergent theme'.

Findings of this work, presented in Table 2, are verified twice. They were first presented in a validation session attended by six prominent Scottish food entrepreneurs. The validation panel concurred with most, but not all, insights that we shared with them. We have indicated the nature of validation panel agreement with our findings and included specific comments at appropriate places. For testing the generalisability of these propositions, a Scotland wide triangulation survey of innovative companies was subsequently conducted for all firm sizes in food as well as non-food sectors. However, before undertaking the survey, the entire evidence was carefully reconsidered. This led to identification of a few new propositions that were not presented to the validation panel. For these propositions, in the column showing validation panel input only ' - ' is entered. The survey found evidence in support of most of the propositions listed here. However, this paper reports only the propositions that came from the case studies. The survey details and its findings are discussed in a forthcoming book.

\section{The case study companies}

The size, age, and product profile of the case study companies is provided in Table 1. 
Table 1: the case study companies

\begin{tabular}{|l|l|l|l|}
\hline Companies & Age & Main products & Employment \\
\hline A & 35 & Pizzas & 50 \\
\hline B & 25 & Pate & 70 \\
\hline C & 23 & Bakery, confectionery & 130 \\
\hline D & 13 & Ice-cream & 14 \\
\hline E & 32 & Haggis, soups, candies, jam & $03^{*}$ \\
\hline F & 17 & Seafood, smoked salmon & 190 \\
\hline G & 9 & Organic Soups and ready meals & 40 \\
\hline
\end{tabular}

*Outsources most of its activities

\section{The findings}

The findings of this research are presented in Table 2 following Eisenhardt's (1989) advice on reporting the case study results. The findings are presented in terms of a set of emergent propositions indicating the relevant theoretical perspectives and constructs, a sample of supporting evidence in form of quotes from the interviews or our own comments. Table 2 also indicates the nature of agreement or its absence with the validation panel and specific comments at appropriate places.

\section{Emergent propositions and received theory: conflict, congruence and consequences}

We have proposed that small food companies do not use formal R\&D to develop new products. This is the behaviour of all case study companies. This is consistent with the food innovation literature (Capitanio, Coppola \& Pascucci, 2010; Galizzi \& Venturini, 1996; Ilori, Oke \& Sanni, 2000 and Jones, 1995). The extant theory, however, unlike us, does not suggest zero incidence of R\&D but only its low intensity. One possible explanation for this variance could be that the cited research explores mixed firms size of whereas our work relate only to SMEs. We explore this issue in more detail later as well as analyse some further relevant literature. 


\begin{tabular}{|c|c|c|c|c|c|c|}
\hline Emerging propositions & $\begin{array}{l}\text { Research } \\
\text { perspective }\end{array}$ & $\begin{array}{l}\text { Theoretical } \\
\text { construct }\end{array}$ & $\begin{array}{l}\text { sub- } \\
\text { construct }\end{array}$ & $\begin{array}{l}\text { Selected illustrative quotes / supporting } \\
\text { comments }\end{array}$ & $\begin{array}{l}\text { Exception } \\
\text { companies }\end{array}$ & Validation panel input \\
\hline $\begin{array}{l}\text { Successful newly developed } \\
\text { products do not significantly } \\
\text { differ from innovative company's } \\
\text { existing products. They are only } \\
\text { variants of its current products. }\end{array}$ & $\begin{array}{l}\text { Innovation } \\
\text { typology }\end{array}$ & $\begin{array}{l}\text { Novelty of } \\
\text { innovation }\end{array}$ & $\begin{array}{l}\text { Incremental } \\
\text { innovation }\end{array}$ & $\begin{array}{l}\text { 'If you think in terms of completely new } \\
\text { products then I have not done that before. } \\
\text { It is always a variation in theme.' }\end{array}$ & None & $\begin{array}{l}\text { Agreement, a panel member } \\
\text { called it 'constant tweaking' }\end{array}$ \\
\hline $\begin{array}{l}\text { New product development } \\
\text { towards more luxuriant and } \\
\text { expensive versions offer better } \\
\text { value for money spent on } \\
\text { innovation. }\end{array}$ & $\begin{array}{l}\text { Context- } \\
\text { causes- } \\
\text { policy- } \\
\text { causes } \\
\text { innovation }\end{array}$ & 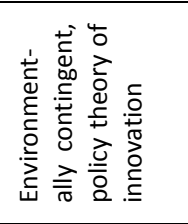 & $\begin{array}{l}\text { Market as } \\
\text { context }\end{array}$ & $\begin{array}{l}\text { '...If we try to go to the low (end of the) } \\
\text { market we will not make money.' }\end{array}$ & None & $\begin{array}{l}\text { Agreement, the process referred } \\
\text { to as 'premiumisation' during the } \\
\text { validation discussion }\end{array}$ \\
\hline $\begin{array}{l}\text { New product development } \\
\text { towards more luxuriant and } \\
\text { expensive versions suits well the } \\
\text { high-variety-low-volume } \\
\text { operations of small food } \\
\text { companies. }\end{array}$ & $\begin{array}{l}\text { Context- } \\
\text { causes- } \\
\text { policy- } \\
\text { causes } \\
\text { innovation }\end{array}$ & 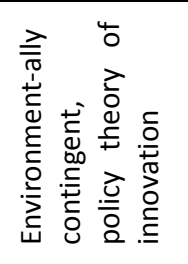 & $\begin{array}{l}\text { Organisation } \\
\text { as context }\end{array}$ & $\begin{array}{l}\text { All case study companies have high- } \\
\text { variety-low-volume operations }\end{array}$ & None & Agreement \\
\hline $\begin{array}{l}\text { Innovative companies use } \\
\text { production methods that are } \\
\text { amenable to quick changes in } \\
\text { final products. }\end{array}$ & $\begin{array}{l}\text { Process } \\
\text { perspective }\end{array}$ & $\begin{array}{l}\text { Process } \\
\text { nature }\end{array}$ & $\begin{array}{l}\text { Flexible } \\
\text { production } \\
\text { methods }\end{array}$ & $\begin{array}{l}\text { '...our ability to change and to change } \\
\text { quickly is far greater than of the larger } \\
\text { manufacturers...' } \\
\text { '...We make small batch runs of specialist } \\
\text { products whereas, the large factories have } \\
\text { automated equipment, and they just can't } \\
\text { do it.' }\end{array}$ & None & $\begin{array}{l}\text { Partial agreement, panel } \\
\text { members felt that flexible } \\
\text { production methods are suitable } \\
\text { during the early stage of NPD. At } \\
\text { the later stage, if the demand } \\
\text { crosses a certain threshold, more } \\
\text { automatic production processes } \\
\text { are needed to exploit the } \\
\text { economies of scale. }\end{array}$ \\
\hline $\begin{array}{l}\text { There is an absence of formal } \\
R \& D \text { in innovative Scottish food } \\
\text { companies }\end{array}$ & $\begin{array}{l}\text { Determinant } \\
\text { perspective }\end{array}$ & $\begin{array}{l}\text { Internal- } \\
\text { strategic } \\
\text { determinant }\end{array}$ & $R \& D$ & $\begin{array}{l}\text { None of the case study companies has an } \\
\text { R\&D facility }\end{array}$ & None & $\begin{array}{l}\text { Agreement, R\&D in the } \\
\text { conventional sense has little role } \\
\text { in innovation by small food } \\
\text { companies }\end{array}$ \\
\hline $\begin{array}{l}\text { Innovative small food companies } \\
\text { do not face significant financial } \\
\text { constraints in new product } \\
\text { development. }\end{array}$ & Determinant & $\begin{array}{l}\text { Internal- } \\
\text { strategic } \\
\text { determinant }\end{array}$ & $\begin{array}{l}\text { Financial } \\
\text { adequacy }\end{array}$ & $\begin{array}{l}\text { '...you don't need masses of data and } \\
\text { research and hire these research } \\
\text { companies to go in and get the product to } \\
\text { the market.' }\end{array}$ & None & - \\
\hline
\end{tabular}




\begin{tabular}{|c|c|c|c|c|c|c|}
\hline Emerging propositions & $\begin{array}{l}\text { Research } \\
\text { perspective }\end{array}$ & $\begin{array}{l}\text { Theoretical } \\
\text { construct }\end{array}$ & $\begin{array}{l}\text { sub- } \\
\text { construct }\end{array}$ & $\begin{array}{l}\text { Selected illustrative } \\
\text { supporting comments }\end{array}$ & $\begin{array}{l}\text { Exception } \\
\text { companies }\end{array}$ & Validation panel input \\
\hline \multirow{2}{*}{$\begin{array}{l}\text { Innovative food companies } \\
\text { remain in regular contact with } \\
\text { their main customers throughout } \\
\text { the product development } \\
\text { process. }\end{array}$} & $\begin{array}{l}\text { Process } \\
\text { perspective }\end{array}$ & Networking & $\begin{array}{l}\text { Retailer } \\
\text { involvement }\end{array}$ & \multirow{2}{*}{$\begin{array}{l}\text { '... if we like the product and if we think it } \\
\text { is going to work, we immediately start to } \\
\text { talk to the customer to get an idea as to } \\
\text { what their reaction is'. } \\
\text { (Please see Appendix A for the list of large } \\
\text { retailers involved with the case study } \\
\text { companies) }\end{array}$} & \multirow[t]{2}{*}{$E^{4}$} & \multirow{2}{*}{$\begin{array}{l}\text { Agreement with the caveat that } \\
\text { it is best that the retailers are } \\
\text { approached only after the } \\
\text { product idea has been internally } \\
\text { validated by the company. }\end{array}$} \\
\hline & $\begin{array}{l}\text { Determinant } \\
\text { perspective }\end{array}$ & $\begin{array}{l}\text { External- } \\
\text { strategic } \\
\text { determinant }\end{array}$ & $\begin{array}{l}\text { Cooperation } \\
\text { and } \\
\text { networking }\end{array}$ & & & \\
\hline $\begin{array}{l}\text { In the food industry, the basic } \\
\text { innovation process is cross- } \\
\text { functional. }\end{array}$ & $\begin{array}{l}\text { Process } \\
\text { perspective }\end{array}$ & $\begin{array}{l}\text { Process } \\
\text { nature }\end{array}$ & $\begin{array}{l}\text { Cross- } \\
\text { functional } \\
\text { Involvement }\end{array}$ & $\begin{array}{l}\text { 'We've got inputs of marketing and we've } \\
\text { got (it) from accounts, production, } \\
\text { technical, and development sides' } \\
\text { 'We all have a look at it from different } \\
\text { sides, as will that work in the factory or } \\
\text { will we be able to sell that, will we be able } \\
\text { to take it off the ground and around that } \\
\text { table if there's a feeling that this is worth a } \\
\text { go then we'll go for it.' }\end{array}$ & None & Agreement \\
\hline $\begin{array}{l}\text { Innovative food companies } \\
\text { exhibit a good fit between } \\
\text { market needs and firm's } \\
\text { resources. }\end{array}$ & Determinant & $\begin{array}{l}\text { Internal- } \\
\text { strategic } \\
\text { determinant }\end{array}$ & $\begin{array}{l}\text { Market } \\
\text { orientation }\end{array}$ & $\begin{array}{l}\text { '...it was purely a decision based on } \\
\text { resources and the effort that we can put } \\
\text { and to which direction to take the } \\
\text { business...' } \\
\text { '...It depends on what the customer wants } \\
\text { and what we can do.' }\end{array}$ & None & - \\
\hline $\begin{array}{l}\text { Innovative food companies } \\
\text { exhibit ability to explore and } \\
\text { reach potential markets. }\end{array}$ & Determinant & $\begin{array}{l}\text { Internal- } \\
\text { strategic } \\
\text { determinant }\end{array}$ & $\begin{array}{l}\text { Market } \\
\text { orientation }\end{array}$ & $\begin{array}{l}\text { 'Our company was predominantly a } \\
\text { corner-shop supplier... in the last } 3 \text { years } \\
\text { we have concentrated a lot on the } \\
\text { supermarkets. We now supply (to) ASDA, } \\
\text { Morrisons-cum-Safeway, Aldi stores, } \\
\text { Scotmid, Sainsbury and Waitrose.' }\end{array}$ & None & - \\
\hline
\end{tabular}

\footnotetext{
${ }^{4}$ Company E does not deal with large retailers. It exports its products to USA to be sold to expatriate Scots via Scottish and Irish souvenir shops and sells them in Scotland through Scottish gift shops.
} 


\begin{tabular}{|c|c|c|c|c|c|c|}
\hline Emerging propositions & $\begin{array}{l}\text { Research } \\
\text { perspective }\end{array}$ & $\begin{array}{l}\text { Theoretical } \\
\text { construct }\end{array}$ & $\begin{array}{l}\text { sub- } \\
\text { construct }\end{array}$ & $\begin{array}{l}\text { Selected illustrative } \\
\text { supporting comments }\end{array}$ & $\begin{array}{l}\text { Exception } \\
\text { companies }\end{array}$ & Validation panel input \\
\hline $\begin{array}{l}\text { Innovative food companies have } \\
\text { a good understanding of } \\
\text { customer needs and user } \\
\text { circumstances. }\end{array}$ & Determinant & $\begin{array}{l}\text { Internal- } \\
\text { strategic } \\
\text { determinant }\end{array}$ & $\begin{array}{l}\text { Market } \\
\text { orientation }\end{array}$ & $\begin{array}{l}\text { '...at the end of the day it is a consumer } \\
\text { who drives any business and the consumer } \\
\text { trends are changing very quickly from one } \\
\text { product range to another. We deal with } \\
\text { clients that aren't big enough to well } \\
\text { customize our stock... We on the other } \\
\text { hand understand the need for quality } \\
\text { products in the pizza market...' }\end{array}$ & None & - \\
\hline $\begin{array}{l}\text { Creative People with high } \\
\text { innovative proclivity play crucial } \\
\text { roles in new product } \\
\text { development in the food } \\
\text { industry. }\end{array}$ & Determinant & $\begin{array}{l}\text { Internal- } \\
\text { non- } \\
\text { strategic } \\
\text { determinant }\end{array}$ & 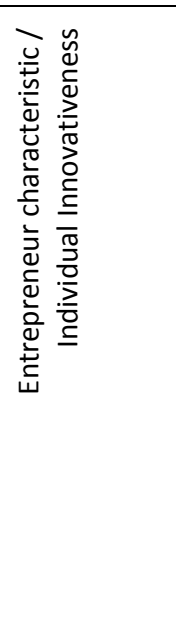 & $\begin{array}{l}\text { '(I get new product ideas) all the time. } \\
\text { Continues to come and go.' } \\
\text { '... If we brainstorm our chef, he will give } \\
\text { you } 30 \text { ideas... I could do the same and } \\
\text { Steve }{ }^{5} \text { would probably come out with 100.' } \\
\text { All the six respondents, who returned an } \\
\text { innovation potential indicator } \\
\text { questionnaire (Patterson, 2001) in the } \\
\text { investigation, have higher scores on both } \\
\text { 'Motivation to Change' and 'Challenging } \\
\text { Behaviour', indicators of innovative } \\
\text { behaviour than on 'Adaptation' and } \\
\text { 'Consistency of Work Styles', indicators of } \\
\text { lack of creativity. }\end{array}$ & None & $\begin{array}{l}\text { No comments from the panel, } \\
\text { may be the panel members did } \\
\text { not deem it appropriate to talk } \\
\text { about their own creativity in the } \\
\text { midst of their peers. We did not } \\
\text { press them. }\end{array}$ \\
\hline $\begin{array}{lcr}\text { In innovative } & \text { Scottish } & \text { food } \\
\text { companies, cooperation } & \text { and } \\
\text { networking } & \text { exists } & \text { with } \\
\text { customers, } & & \text { suppliers, } \\
\text { competitors } & \text { and } & \text { Scottish } \\
\text { Enterprise. } & & \end{array}$ & Determinant & $\begin{array}{l}\text { External- } \\
\text { strategic } \\
\text { determinant }\end{array}$ & $\begin{array}{l}\text { Cooperation } \\
\text { and } \\
\text { networking }\end{array}$ & $\begin{array}{l}\text { Please see Appendix B for details of nature } \\
\text { of networking by the case study } \\
\text { companies }\end{array}$ & None & $\begin{array}{l}\text { Partial agreement, some panel } \\
\text { members not happy with the } \\
\text { support from the Scottish } \\
\text { Enterprise }\end{array}$ \\
\hline
\end{tabular}

\footnotetext{
${ }^{5}$ Not his real name
} 


\begin{tabular}{|c|c|c|c|c|c|c|}
\hline Emerging propositions & $\begin{array}{l}\text { Research } \\
\text { perspective }\end{array}$ & $\begin{array}{l}\text { Theoretical } \\
\text { construct }\end{array}$ & $\begin{array}{l}\text { sub- } \\
\text { construct }\end{array}$ & $\begin{array}{l}\text { Selected illustrative } \\
\text { supporting comments }\end{array}$ & $\begin{array}{l}\text { Exception } \\
\text { companies }\end{array}$ & Validation panel input \\
\hline $\begin{array}{l}\text { Within small Scottish food } \\
\text { companies, innovation is not } \\
\text { focused on development of } \\
\text { health foods }\end{array}$ & $\begin{array}{l}\text { Context- } \\
\text { causes- } \\
\text { policy- } \\
\text { causes } \\
\text { innovation }\end{array}$ & 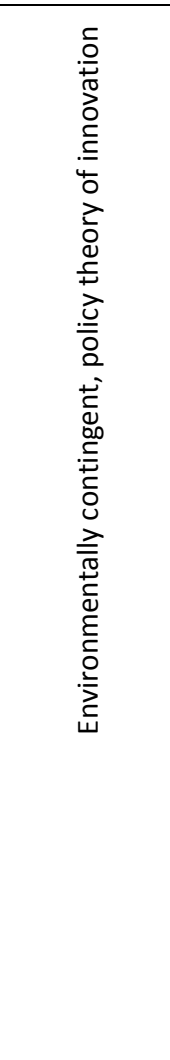 & $\begin{array}{l}\text { Cultural } \\
\text { context of } \\
\text { food } \\
\text { consumption }\end{array}$ & $\begin{array}{l}\text { '...majority of them (our new products) } \\
\text { are more indulgent ones, and it's not } \\
\text { something that you have daily.' } \\
\text { 'Scotland has not got the income where } \\
\text { people can afford it. Scotland has not got } \\
\text { the pollution where people would feel that } \\
\text { they must buy organic and we (the } \\
\text { Scottish people) are not as ... trend setters } \\
\text {...' } \\
\text { '...dealers want chocolates full of fat, } \\
\text { custard full of fat, everything full of fat; } \\
\text { even salad, full of fat. Everything has (to } \\
\text { have) fat in it...' } \\
\text { '...people who buy Scottish cake, Irn Bru, } \\
\text { Square Sausage, Mars Bars and things like } \\
\text { that, they don't buy low fat products.' } \\
\text { 'We have been told by ... (names the } \\
\text { retailer)... that your attempt to make low } \\
\text { fat, low sugar cakes is commendable but } \\
\text { we will not take them because people will } \\
\text { not buy them, they taste horrible.' }\end{array}$ & $G^{6}$ & $\begin{array}{l}\text { Surprise, they had thought that } \\
\text { 'premiumisation' and 'health } \\
\text { food' were two most likely } \\
\text { sources of growth through NPD. } \\
\text { They still argued that health- } \\
\text { food is a growing niche and } \\
\text { hoped that more Scottish food } \\
\text { companies will explore its } \\
\text { potential in the long run. }\end{array}$ \\
\hline
\end{tabular}

\footnotetext{
${ }^{6}$ Company $\mathrm{G}$ is a young health food company focussed on organic foods.
} 
The other proposition, congruent with extant literature relate to food sector innovation being predominantly incremental (Bhaskaran, 2006; Bogue \& Ritson, 2006; Ernst \& Young, 1999; Koku, 1998 and Martinez \& Briz, 2000). Our findings however, beyond confirming the incremental nature of food and drinks innovation addresses a significant knowledge gap. We postulate that the focus of incremental innovation in this sector is 'premiumisation' or development of products to be positioned at the higher end of value chain. We also hypothesise a rationale for this NPD accent and propose that high-variety-low-volume manufacturing environment of case study companies makes it obligatory for them to charge a premium to recover their NPD costs from the sale of newly developed products. Our proposition, thus, goes beyond 'what happens' and answers 'why it happens' (Whetten, 1989) a question not yet not answered by the extant literature.

The literature shows that large MNCs in this sector that maintain large R\&D budgets in search for radical new products do not succeed consistently in their efforts and successful amongst them are few (Alfranca, Rama \& von Tunzelmann, 2004). In the light of this, our proposition that small food companies do not invest in R\&D to develop new food products highlights the contrasting behaviour of enterprises at the two ends of the firm-size spectrum and shows that small food companies follow an innovation path not only different from the one taken by their larger counterparts, given their resource endowments, their approach to new product development is more realistic.

Nystrom \& Edvardsson (1982) and Galizzi \& Venturini (1996) attribute the focus on incremental innovation, avoidance of perceived 'unnecessary' high R\&D budgets and low research intensity in this sector to food consumers' conservatism. Interestingly Galizzi \& Venturini (1996) also show a weak relationship between $R \& D$ intensity and innovation in the food industry. Analysing these two 
findings in combination with our relevant propositions generates an interesting insight. Prospects of achieving commercial success through incremental innovation that does not necessitate investment in R\&D along with inability of R\&D to deliver innovation with some certainty, explains long-standing tradition of incremental innovation and aversion of formalised R\&D by SMEs in the food and drinks industry.

Our proposition on health food development avoidance by small food companies complements the findings of Bogue \& Ritson (2006) and augments the extant theory. Juxtaposing 'premiumisation' emphasis of innovative food SMEs, reported by us, with Bogue \& Ritson's (2006) research reporting the failure of new health foods to generate the promised premiums explains why innovative small food companies avoid developing health foods and why this trend is likely to continue.

Another proposition relevant here is noteworthy large-retailer engagement with small food and drinks firm's NPD. This is echoed in the extant literature (Colurcio et al. 2012; Fortuin \& Omta, 2009; Hughes, 1997; Spiekermann, 2009 and Stewart-Knox \& Mitchell, 2003). Hingley \& Hollingsworth (2003) however clarify that large-retailer's motives for this is to ensure that partner SMEs create products that could be positioned at the high-end of the value chain so that they can compete with dominant food MNCs. When we combine this with our proposition that high-variety-low-volume manufacturing environment of food SMEs obligates that they develop premium products, it supplements the existing literature, extends the received wisdom and underpins the fact that the two allies in this process share a NPD emphasis, though for a very diverse reasons, they both achieve their respective goals. This explains why such partnerships continue to flourish and proliferate. 
Our proposition on within-firm cross-functional cooperation is in congruence with the food NPD literature (Capitanio, Coppola \& Pascucci., 2010; Dhamvithee et al., 2005 and Suwannaporn \& Speece, 2000, 2003). Findings in the literature on innovative food company's high responsiveness to changes in consumer preferences, their flexibility and emphasis on product quality (Bogue, 2001), (Bogue, 2001) involvement of top management in product development (Ilori, Oke \& Sanni, 2000), the quality of human capital (Fortuin \& Omta, 2009) and market and consumer knowledge (Stewart-Knox \& Mitchell, 2003) too are consistent with our postulations. However, our research provides limited evidence on regional networking (Gellynck, Vermeire \& Viaene, 2007; Karantininis, Sauer \& Furtan, 2010), export orientation (Karantininis, Sauer \& Furtan, 2010) and outsourcing of activities (Spaulding \& Woods, 2006).

\section{A concluding statement on emergent theory}

We postulate that small firm food innovation is shaped exogenously by the cultural context of food consumption and internally by a high-variety-low-volume manufacturing environment. These two influences together lead the food companies to choose the incremental innovation option resulting in development of high-end variants of company's existing products and more specifically 'indulgences' rather than the highly touted health-foods. This product development strategy dispenses with need for R\&D investments. To combat the competitive pressures exerted by large food companies, the small food enterprises use production methods amenable to quick changes in manufacturing processes and in this battle of the unequal, they seek and get the support of large retailers whose reach and influence in the food market is significant and growing. The large retailers, who too are in competition with large food MNCs, use these agile small companies' creativity and flexibility to achieve their own competitive goals. Within their own small sphere of 
influence and in a game of limited financial stakes, the small food companies appear to be successful. In contrast, the success of the largest in their trade in search for radical new products, driven by huge investments in R\&D is less spectacular. This happens, we theorise, due to a comparatively superior understanding of the cultural context of food consumption by the small food companies vis-à-vis their larger counterparts.

The postulations outlined here extend and modify our understanding of product innovation in food industry due to our sharper focus on small low-tech companies in contrast to the extant literature, which springs largely from investigation of mixed firm sizes and mixed technology orientations.

\section{Limitations}

The research process used here has some limitations. To start with, the case studies companies, all SMEs within the employment definition, reflect a significant intra-sample size variation from 14 to 190 employees ${ }^{7}$. Further, two separate companies in the sample differ from the rest each on one specific count. $\mathrm{G}$ is a health-food company while the rest are not and $\mathrm{E}$ is export driven and does not supply to supermarkets unlike the rest. Presence of these companies in the investigation influences its results both ways. It reduces the supporting weight of the emergent propositions. However, they also afford us an opportunity to contrast the deviant behaviour with the dominant behaviour and underscore an important fact. In a seemingly identical context, some entities may act differently and theoretical propositions emerging from an investigation such as this may not be universally applicable. Thirdly, though our findings come by interviewing people in seven companies, only five interviews are digitally recorded. The summaries of the remaining two interviews that were written down subsequently do not provide equally rich details vital for theory

\footnotetext{
${ }^{7}$ Excluding Company E, that outsources most of its activities.
} 
building. Finally, though we have included 15 propositions in this paper, four of these were not discussed with the validation panel and we are unable to know what the panel might have opined on these. The reason for their inclusion here is that they were a part of a subsequent Scotland wide survey of companies that have successfully developed new products and we thought it fit to include them in this exploration to present a more complete theoretical canvas.

\section{Acknowledgements}

1. Professor Maria Minniti (Syracuse University), Professor Paul Trott and Dr Andreas Hoecht (Portsmouth Business School) for their useful comments on an earlier draft

2. Managing Directors and executives in case studies companies for providing valuable information

3. Professor Ron Masson, Mrs Susan Laing and Mr Aiden Craig (Edinburgh Napier University) for their help in conducting the interviews and for their useful comments

4. Dr Fiona Patterson (Oxford Psychology Group) for sending her innovative personality questionnaire and for permission to use it

5. Scottish food entrepreneurs, Mr Peter Ford, Mr Mark Laing, Ms Jo Macsween, Mr Tony Stone, Ms Lesley McVey and Mr Robin Pollok for their validation session input

\section{References}

1. Abend, Gabriel (2008) The Meaning of 'Theory', Sociological Theory, 26(2):173-199

2. Acs Z J and Audretsch, D B (1990) Innovation and Small Firms, Cambridge, Mass, MIT Press

3. Alfranca, Oscar, Rama, Ruth and von Tunzelmann, Nicholas (2004) Innovation spells in the multinational agri-food sector, Technovation, 13(6):343-73

4. Anderson, Neil R and West, Michael A (1998) Measuring climate for work group innovation: Development and validation of the team climate inventory, Journal of Organisational Behaviour, 19 (3): 235-258

5. Antonelli, C and Calderini, M (1999) The dynamics of localised technology change, In: Gambardella, A and Malerba, $\mathrm{F}$ (eds) The Organisation of Economic Innovation in Europe, Cambridge University Press, New York, 158-76

6. Avermaete, Tessa, Viaene, Jacques, Morgan, Eleanor J and Crawford, Nick, (2003) Determinants of innovation in small food firms, European Journal of Innovation Management, 6(1): 8-17

7. Bacon, Francis (1902) Novum Organum (ed. Devey, Joseph) P F Collier, New York

8. Barczak, G , Griffin, A and Kahn, K (2009), Trends and Drivers of Success in NPD Practices: Results of the 2003 PDMA Best Practices Study, Journal of Product Innovation Management, 26(1): 3-23

9. Brockhoff, Klaus (1999) Produktpolitik, $4^{\text {th }}$ Edition, UTB, Stuttgart

10. Bartunek, J M, Rynes, S L, and Ireland, R D (2006) What makes management research interesting, and why does it matter? Academy of Management Journal, 49(1): 9-15

11. Beaver, Graham and Prince, Christopher (2002) Innovation, entrepreneurship and competitive advantage in the entrepreneurial venture, Journal of Small Business and Enterprise Development, 9(1): 28-37

12. Bhaskaran, Suku (2006) Incremental innovation and business performance: Small and medium-size food enterprises in a concentrated industry environment, Journal of Small Business Management, 44(1)64-80

13. Bogue Joe (2001) New Product Development and the Irish Food Sector: A Qualitative Study of Activities and Processes, Irish Journal of Management, 22(1): 171-191 
14. Bogue, Joe and Ritson, Christopher (2006) Integrating consumer information with the new product development process: the development of lighter dairy products, International Journal of Consumer Studies, 30(1): 44-54

15. Breschi, S (1999) Spatial patterns of innovation: Evidence from patent data In Gambardella, A and Malerba, F (Eds) The Organisation of Economic Innovation in Europe, Cambridge University Press, New York, 71-103

16. Cameron, K and Quinn, R (1988) Organizational paradox and transformation, In Quinn, R and Cameron, K (Eds ), Paradox and transformation: Toward a theory of change in organization and management, Ballinger, Cambridge, MA: 1-18

17. Capitanio, Fabian, Coppola, Adele and Pascucci, Stefano (2010) Product and Process Innovation in the Italian Food Industry, Agribusiness 26(4):503-518

18. Casson, Mark C (2003) The entrepreneur: An economic theory, Second Edition, Edward Elgar Publishing

19. Cavanagh R E and Clifford, D K (1983) Lessons from America's mid-sized growth companies, The Mckinsey Quarterly Autumn (3): 2-23

20. Cohen, W M and Levinthal, D A (1990) Absorptive capacity: A new perspective on learning and innovation, Administrative Science Quarterly, 35 (1): 128-52

21. Colurcio, Maria, Wolf, Patricia, Kocher, Pierre-Yves, Russo-Spena, Tiziana, (2012) Asymmetric relationships in networked food innovation processes, British Food Journal, 114(5):702-727

22. Conway, S and Steward F (2009) Managing and shaping innovation, Oxford University Press, Oxford

23. Cooper R G (1990) Stage-Gate Systems: A New Tool for Managing New Products, Business Horizons, 33(3):44-54

24. Cooper R G (2008) Perspective: The Stage-Gate ${ }^{\circledR}$ Idea-to-Launch Process-Update, What's New, and NexGen Systems Journal of Product Innovation Management, 25(3): 213-232

25. Cooper, R G \& Kleinschmidt, E J (1994) Determinants of timeliness in product development, Journal of Product Innovation Management 11(5): 381-396

26. Denzin, Norman K., and Lincoln, Yvonna S (1994) Introduction: Entering the Field of Qualitative Research, in Handbook of Qualitative Research, Norman K. Denzin and Yvonna S. Lincoln, (eds.) Sage Publications, Thousand Oaks, CA. 1-17.

27. Dhamvithee, Pisit, Shankar, Bhavani, Jangchud, Anuvat and Wuttijumnong, Phaisarn (2005) New product development in Thai Agro-Industry: Explaining the rates of innovation and success in innovation, International Food and Agribusiness Management Review, 8(3): 1-19

28. Dosi, Giovanni (1988) Sources, procedures and microeconomic effects of innovation, Journal of Economic Literature, 26 (3): 1120-1171

29. Easterby-Smith, M, Lyles, M A and Peteraf, M A (2009) Dynamic capabilities: current debates and future directions, British Journal of Management, 20(1): S1-S8

30. Edwards, Tim, Delbridge, Rick and Munday, Max (2005) Understanding innovation in small and mediumsized enterprises: A process manifest, Technovation, 25(10): 1119-1127

31. Eisenhardt, K M (1989) Building theories from case study research, Academy of Management Review, 14(4):532-550

32. Eisenhardt, Kathleen M And Graebner Mellissa A (2007) Theory building from cases: Opportunities and challenges, Academy of Management Journal, 50(1): 25-32

33. Ernst \& Young (1999) New product introduction, Successful innovation/failure: a fragile boundary, Paris: Ernst \& Young Global Client Consulting

34. Ettlie, J E and Bridges, W P (1982) Environmental Uncertainty and Organizational Technology, IEEE Transactions on Engineering Management, 29 (1): 2-10

35. Ettlie, John E (1983) Organizational Policy and Innovation among Suppliers to the Food Processing Sector, The Academy of Management Journal, 26(1): 27-44

36. Ettlie, John E and Elsenbach Jorg M (2007) Modified Stage-Gate Regimes in New Product Development, Journal of Product Innovation Management, 24(1):20-33

37. Fortuin, Frances T J M and Omta, S W F (Onno) (2009) Innovation drivers and barriers in food processing, British Food Journal, 111(8):839-851

38. Freeman, C (1974) The Economics of Industrial Innovation, Penguin Books, Harmondsworth 
39. Frenz, Marion, Michie, Jonathan and Oughton, Christine (2003) Regional dimension of innovation: Results from the third Community Innovation Survey, International Workshop: Empirical Studies on Innovation in Europe, Faculty of Economics, University of Urbino

40. Galizzi G and Venturini L (1996) Economics of Innovation: The case of food industry, Physica-Verlag, Heidelberg

41. Garcia, R and Calantone, R (2002) A critical look at technological innovation typology and innovativeness terminology: a literature review Journal of Product Innovation Management, 19(2) : 110-132

42. Gellynck, Xavier, Vermeire, Bert and Viaene, Jacques (2007) Innovation in food firms: contribution of regional networks within the international business context, Entrepreneurship \& Regional Development: An International Journal, 19(3): 209-226

43. Grabowski, H G and Mueller, D C (1978) Industrial Research and Development, Intangible Capital Stocks and Firm Profit Rates, Bell Journal of Economics 9(2):328-343

44. Greenwood, Royston and Hinings, C R (1993) Understanding Strategic Change: The Contribution of Archetypes, The Academy of Management Journal, 36(5): 1052-1081

45. Hingley, M, \& Hollingsworth, A (2003) Competitiveness and power relationships: Where now for the UK food supply chain? Proceedings, the 19th Annual IMP Conference, Lugano, Switzerland

46. Hirsch-Kreinsen, Hartmut (2008) "Low-Tech" innovations, Industry and Innovation 15(1): 19-43

47. Hoholm, Thomas and Araujo, Luis (2011) Studying innovation processes in real-time: The promises and challenges of ethnography Industrial Marketing Management 40(6): 933-939

48. Hughes, Alex (1997) The Changing Organization of New Product Development for Retailers' Private Labels: A UK-US Comparison, Agribusiness 13(2): 169-184

49. Huq $M$ and Toyama M (2006) An analysis of factors influencing the development of new products in the Thai food industry, International Journal of Technology Management and Sustainable Development 5(2): 159-172

50. Ilori, M O, Oke J S and Sanni S A (2000) Management of new product development in selected food companies in Nigeria, Technovation, 20(6): 333-342

51. Johannessen, J A, Olsen, B and Lumpkin G T (2001) Innovation as newness: What is new, how new, and new to whom? European Journal of Innovation Management 4(1): 20- 31

52. Jones, Peter (1995) Developing new products and services in flight catering, International Journal of Contemporary Hospitality Management, 7:(2)24-28

53. Karantininis, K, Sauer, J and Furtan, W H (2010) Innovation and integration in the agri-food industry, Food Policy, 35(2): 112-120

54. Kohli, A K and Jaworski, B J (1990) Market orientation: The construct, research propositions, and managerial implications, Journal of Marketing 54(2): 1-18

55. Koku, Paul Sergio's (1998) Innovation and information management in the food industry, British Food Journal, 100(6):278-285

56. Krishnan, V, Eppinger, S D and Whitney, D E (1997) A model based framework to overlap product development activities, Management Science, 43(4): 437-451

57. Leatherhead Food International (2005) The Scottish Food and Drinks Report

58. Longman, B (2001) Future Innovations in Food 2001: Forward-Focused NPD and Maximizing Brand Value, Reuters Business Insight, London

59. Mansfield E (1968) The Economics of Technological Change, W W Norton

60. Mansfield E (1971) Research and Innovation in the Modern Corporation, W W Norton

61. Mark-Herbert, Cecilia (2004) Innovation of a new product category-functional foods, Technovation, 24(9): 713-719

62. Martinez, Garcia Marian and Briz, Julian (2000) Innovation in the Spanish Food and Drinks Industry, International Food and Agribusiness Management Review, 3(2): 155-176

63. Menrad, K (2004) Innovations in the food industry in Germany, Research Policy 33(6-7): 845-878

64. Mintzberg, H (1979) An emerging strategy of direct research, Administrative Science Quarterly, 24, 580589

65. Moore, B (1995) What differentiates innovative small firms? Innovation Initiative Paper No 4, ESRC Centre for Business Research, University of Cambridge 
66. Morgan, Gareth and Smircich, Linda (1980) Case for Qualitative Research, The Academy of Management Review , 5(4):491-500

67. Muscio, Alessandro, Nardone, Gianluca and Dottore, Antonio (2010) Understanding demand for innovation in the food industry Measuring Business Excellence 14(4): 35-48

68. Ngamkroeckjoti, Chittipa, Speece, Mark and Dimmitt, Nicholas J (2005) Environmental scanning in Thai food SMEs: The impact of technology strategy and technology turbulence, British Food Journal 107(5): 285-305

69. Nonaka, I and Takeuchi, H (1995) The Knowledge Creating Company, Oxford University Press, Oxford

70. Nystrom, Harry and Edvardsson, Bo (1982) Product innovation in food processing - a Swedish Survey, $R$ \& D Management, 12(2):67-72

71. O'Gorman, Colm, (1997) Success Strategies in High Growth Small and Medium-Sized Enterprises, In JonesEvans, Dylan and Klofsten, Magnus (eds) Technology, Innovation and Enterprise: The European Experience, Palgrave Macmillan

72. Oakey, Ray, Rothwell, Roy and Cooper, Sarah (1988) Management of Innovation in High Technology Small Firm: Innovation and Regional Development in Britain and the United States, London: Pinter Publisher

73. Patterson, F (2001) The Innovation Potential Indicator: Test Manual and Users Guide, Oxford Psychologists Press, Oxford

74. Pavitt, K (1991) Key characteristics of the large innovative firm, British Journal of Management 2(1): 41-50

75. Petrou, Anastasia and Daskalopoulou, Irene (2009) Innovation and small firms' growth prospects: relational proximity and knowledge dynamics in a low-tech industry European Planning Studies 17(11): 1591-1604

76. Pettigrew, Andrew M (1990) Longitudinal field research on change: Theory and practice, Organization Science, 1(3):267-292

77. Rama, Ruth (2008) (Ed) Handbook of innovation in the food and drinks industry, The Howarth Press, Taylor \& Francis Group, New York and London

78. Robertson, P L, Smith, K and von Tunzelmann, N (2009) Innovation in low- and medium-technology industries, Research Policy, 38(3): 441-446.

79. Roper, S (2000) Benchmarking Regional Innovation: A Comparison of Baden-Wurttemberg, Bavaria, Northern Ireland and the Republic of Ireland, Working Paper, No 56, Northern Ireland Economic Research Centre, Belfast

80. Rothwell, Roy and Zegveld, Walter (1982) Innovation and the Small and Medium Sized Firm: Their Role in Employment and in Economic Change, London: Frances Pinter

81. Russo Spena, Tiziana and Colurcio, Maria (2010) A Cognitive-Relational View Of Innovation In The AgriFood Industry: The Fresh-Cut Business, International Journal of Innovation Management, 14(2): $307-329$

82. Sandven, Tore and Smith, Keith (1993) Innovation activities and industrial structure: Industry and R\&D in a comparative context, European Innovation Monitoring System, EIMS Publication, 1, Luxembourg: European Commission, Directorate General XII

83. Sandven, Tore, Smith, Keith and Kaloudis, Aris (2005) Structural change, growth and innovation: the roles of medium and low-tech industries, 1980-2000, In Hirsch-Kreinsen, Hartmut, Jacobson David and Laestadius, Stefan (eds) Low-Tech Innovation in The Knowledge Economy Petr Lang Frankfurt

84. Sankaran, Jayaram K and Mouly Suchitra V (2007) Managing innovation in an emerging sector: the case of marine-based nutraceuticals, R\&D Management, 37(4): 329-344

85. Schumpeter, Joseph A. (1934) The Theory of Economic Development, Harvard University Press, Cambridge

86. Schumpeter, Joseph A. (1942) Capitalism, Socialism and Democracy, Harper \& Row, New York

87. Scottish Business Statistics (2010)

88. Slater, Stanley F and Olson, Eric M (2001) Marketing's contribution to the implementation of business strategy: an empirical analysis, Strategic Management Journal 22(11):1055-1067

89. Spaulding, Aslıhan D and Woods, Timothy A (2006) An Analysis of the Relationship between Supply-Chain Management Practices and New Product Development Time: A Case of the North American Confectionery Manufacturers, Journal of Food Distribution Research, 37(2): 1-11.

90. Spiekermann, Uwe (2009) Twentieth-Century Product Innovations in the German Food Industry, Business History Review 83(2): 291-315 
91. Stewart-Knox, Barbara and Mitchell, Peter (2003) What separates the winners from the losers in new food product development? Trends in Food Science \& Technology 14(1): 58-64

92. Suwannaporn, Prisana and Speece, Mark (2000) Continuous learning process in new product development in the Thai food-processing industry, British Food Journal 102(8): 598- 614

93. Suwannaporn, Prisana and Speece, Mark (2003) Marketing research and success factors for new product development in Thai food processing, Agribusiness, 19 (2): 169-188.

94. van der Valk, Wendy and Wynstra, Finn (2005) Supplier involvement in new product development in the food industry, Industrial Marketing Management 34(7): 681- 694

95. von Tunzelmann, N and Acha, N (2005) Innovation in low tech industries, In: J Fagerberg, D C Mowery \& R R Nelson (eds), The Oxford Handbook in Innovation, Oxford University Press, Oxford

96. Weick, Karl (2007) The Generative Properties of Richness, Academy of Management Journal, 50(1):14-19

97. Whetten, David A (1989) What constitutes a theoretical contribution? Academy of Management review, 14(4):490-495

98. Wilson, Elizabeth J and Vlosky, Richard P (1997) Partnering Relationship Activities from Case Study Research, Journal of Business Research, 39(1): 59-70

99. Wolfe, R A (1994) Organisational innovation: Review, critique and suggested research directions, Journal of Management Studies, 31(3): 405-431

Appendix A

\begin{tabular}{|l|l|}
\hline Company & Main customers \\
\hline A & ASDA, Morrisons, Sainsbury \\
\hline B & ASDA, Morrisons, Sainsbury, Tesco \\
\hline C & ASDA, Morrisons, Aldi, Scotmid, Sainsbury, Waitrose \\
\hline D & Tesco, Sainsbury, Morrisons \\
\hline F & M\&S, Waitrose, Tesco, Morrisons \\
\hline G & Tesco \\
\hline
\end{tabular}

Appendix B

\begin{tabular}{|l|l|l|}
\hline Company & Networks with & For \\
\hline A & Other food companies, Scottish Enterprise & Marketing \\
\hline \multirow{2}{*}{ B } & Other food companies, suppliers, customers & New product development \\
\cline { 2 - 3 } & Scottish Enterprise & Training, design development, marketing, cash flow \\
\hline C & Other food companies & New product development \\
\hline \multirow{2}{*}{ D } & Other food companies & Acquisition of equipment \\
\cline { 2 - 3 } & Scottish Enterprise & Feasibility studies \\
\hline E & Scottish Enterprise & New product development \\
\hline \multirow{2}{*}{ F } & Other companies in the same product group & General cooperation \\
\cline { 2 - 3 } & Customers & New product development \\
\hline G & Scottish Enterprise & General help \\
\hline
\end{tabular}

